\title{
ANALYSIS OF THE COMMUNITY SUPPORTED AGRICULTURE MODEL IN BRAZIL FROM THE POINT OF VIEW OF THE TRANSACTION COST ECONOMIC
}

\section{ANÁLISIS DEL MODELO AGRICULTURA APOYADA POR LA COMUNIDAD EN BRASIL DESDE EL PUNTO DE VISTA DEL COSTE DE LA TRANSACCIÓN ECONÓMICO}

\section{ANÁLISE DO MODELO AGRICULTURA SUPORTADA PELA COMUNIDADE NO BRASIL DO PONTO DE VISTA DA ECONOMIA DOS CUSTOS DE TRANSAÇÃO}

\author{
Liliane Ubeda Morandi Rotoli ${ }^{1}$ \\ Andréa Rossi Scalco ${ }^{2}$ \\ Giuliana Aparecida Santini Pigatto ${ }^{3}$
}

\begin{abstract}
The marketing relationship between farmers and consumers generates transaction costs, and these costs can be minimized through use of an appropriate governance structure. The main objective of this paper was to analyze the governance structure of Community Supported Agriculture in the State of São Paulo, Brazil, in order to identify whether it favors coordination between agents and promotes the reduction of transaction costs. The investigation followed a qualitative-quantitative approach according to the survey research method. For this, it was described the characteristics of the institutional environment in order to understand the aspects that delimit the behavior of the agents and that influence the structure of governance between the agents, as well as identifying the characteristics of transactions and agents (farmers and consumers), from the viewpoint of Transaction Cost Economics. The analysis of the characteristics of the agents showed that there is limited rationality in the perception of consumers; the characteristics of the transactions indicated a
\end{abstract}

\footnotetext{
${ }^{1}$ Bachelor's at Mathematic from Universidade Estadual Paulista Júlio de Mesquita Filho (2006) and master's at Economy from Universidade de São Paulo (2010) and master-s at Agribusiness and Development from Universidade Estadual Paulista. Has experience in Probability and Statistics. São Paulo. Brazil. ORCID: https://orcid.org/0000-0002-4467-3034. E-mail: lilianemorandi@yahoo.com.br

${ }^{2}$ Graduated in Food Engineering from the São Paulo State University (1995), master's degree in Production Engineering from the Federal University of São Carlos (1999) and PhD in Production Engineering from the Federal University of São Carlos (2004). She is currently a researcher at CEPEAGRO and an assistant professor at the São Paulo State University, working mainly on quality management, urban agriculture and organizational studies. In this institution she teaches the Administration course and the master's degree in Agribusiness and Development. Between the years of 2014 and in 2015 she underwent post-doctoral training at Santa Clara University, in the United States of America. Universidade Estadual Paulista Júlio de Mesquita Filho. São Paulo. Brazil. ORCID: https://orcid.org/0000-0001-8039-9450. E-mail: andrea.scalco@,unesp.br ${ }^{3}$ Graduate at Economic Sciences from Universidade Estadual Paulista Júlio de Mesquita Filho (1999), master's at Production Engineering from Universidade Federal de São Carlos (2002) and ph.d. at Production Engineering from Universidade Federal de São Carlos (2006) and in 2019 she underwent post-doctoral training at. Has experience in Economy, focusing on Industrial Organization and Industrial Studies, acting on the following subjects: inovação tecnológica, indústria de sementes, cadeia avícola, marketing and lei de proteção aos cultivares. Universidade Estadual Paulista. São Paulo. Brazil. ORCID: https://orcid.org/0000-0001-9737-6036. E-mail: giuliana.santini@unesp.br.
}

DRd - Desenvolvimento Regional em debate (ISSNe 2237-9029) V. 11, p. 48-70, 2021 
high level of locational, temporal, physical and brand specificity, in addition to the technological specificity in the farmers' perceptions; and the frequency of transactions is high. The assessed scenario shows that the specified governance structure is the hybrid - with the bilateral dependence between autonomous actors and, although adequate, requires improvements in reducing uncertainty among agents. This article brings scientific contributions by relating the theoretical approach of Transaction Cost Economics to the short channels of food production and consumption and, mainly, in the state of São Paulo, Brazil, where these channels have grown in the last decade.

Keywords: Commercialization channel. Institutional environment. Governance structure.

\section{RESUMEN}

Las transacciones entre agricultores y consumidores generan costos, y estos costos pueden minimizarse utilizando la estructura de gobernanza más adecuada. El objetivo principal de este estudio fue analizar la estructura de gobernanza utilizada en la Agricultura Apoyada Comunitaria en el Estado de São Paulo, Brasil, con el fin de identificar si favorece la coordinación entre agentes y promueve la reducción de costos de transacción. La investigación siguió un enfoque cualitativo-cuantitativo, según el método de investigación por encuesta. Se describieron las características del entorno institucional con el fin de comprender los aspectos que delimitan el comportamiento de los agentes y que influyen en la estructura de gobernanza entre los agentes, además de identificar las características de las transacciones y agentes (agricultores y consumidores), desde el punto vista de la Economía de Costos de Transacción. El análisis de las características de los agentes mostró que existe una racionalidad limitada en la percepción de los consumidores; las características de las transacciones indicaron un alto nivel de especificidad local, temporal, física y de marca, además de la especificidad tecnológica en las percepciones de los agricultores; y la frecuencia de las transacciones es alta. Los resultados indicaron que la estructura de gobernanza utilizada es la híbrida con dependencia bilateral y, aunque adecuada, requiere mejoras en la reducción de la incertidumbre entre los agentes. Este artículo trajo contribuciones científicas al relacionar el enfoque teórico de la Economía de los Costos de Transacción con los canales cortos de producción y consumo de alimentos y, principalmente, en el estado de São Paulo, Brasil, donde estos canales han crecido en la última década.

Palabras clave: Canal de comercialización. Ambiente institucional. Estructura de gobierno.

\section{RESUMO}

As transações entre agricultores e consumidores geram custos, e esses custos podem ser minimizados usando-se a estrutura de governança mais apropriada. $\mathrm{O}$ principal objetivo deste estudo foi analisar a estrutura de governança utilizada na Agricultura Suportada pela Comunidade no Estado de São Paulo, Brasil, a fim de identificar se a mesma favorece a coordenação entre os agentes e promove a redução dos custos transacionais. A pesquisa seguiu uma abordagem qualitativa-quantitativa, de acordo com o método de pesquisa survey. Foram descritas as características do ambiente institucional, a fim de compreender os aspectos que delimitam o comportamento dos agentes e que influenciam a estrutura de governança entre os agentes, além de identificar as características das transações e dos agentes (agricultores e consumidores), do ponto de vista da Economia dos Custos de Transação. A análise das características dos agentes mostrou que há racionalidade limitada na percepção

DRd - Desenvolvimento Regional em debate (ISSNe 2237-9029) 
dos consumidores; as características das transações indicaram um alto nível de especificidade local, temporal, física e de marca, além da especificidade tecnológica nas percepções dos agricultores; e a frequência nas transações ser de nível alto. Os resultados indicaram que a estrutura de governança utilizada é a híbrida com dependência bilateral e, embora adequada, requer melhorias na redução da incerteza entre os agentes. Esse artigo trouxe contribuições científicas ao relacionar a abordagem teórica de Economia dos Custos de Transação aos canais curtos de produção e consumo de alimentos e, principalmente, no estado de São Paulo, Brasil, onde há crescimento desses canais na última década.

Palavras-chave: Canal de comercialização, ambiente institucional, estrutura de governança.

Como citar este artigo: ROTOLI, Liliane Ubeda Morandi; SCALCO, Andréa Rossi; PIGATTO, Giuliana Aparecida Santini. Analysis of the community supported agriculture model in Brazil from the point of view of the transaction cost economic. DRd Desenvolvimento Regional em debate, v. 11, p. 48-70, 28 abr. 2021. DOI: https://doi.org/10.24302/drd.v11.2779

Artigo recebido em: $31 / 03 / 2020$

Artigo aprovado em: 08/03/2021

Artigo publicado em: 28/04/2021

\section{INTRODUCTION}

Brazilian organic products have gained notable participation in the production and consumption scenarios in recent years. The 2017 Agricultural Census identified 64,690 certified producers who practiced organic agriculture (BRASIL, 2017), a number ten times higher compared to the previous Agricultural Census, which indicated 5,106 producers in the year 2006. In terms of consumption, the national organic food market has been growing at an average rate of $20 \%$ per year (ORGANICSNET, 2016). It is estimated that most national organic products are marketed in traditional channels, such as supermarkets and hypermarkets, which together hold $80 \%$ of sales of organic food and beverages (IPD, 2011).

Despite this evolution in the production and consumption of organic products, the distribution of products, especially from small farmers, is a barrier to be overcome. Marketing through supermarket chains and intermediaries occurs through exigencies and impositions of conditions that often lead to commercial abuses towards farmers (ARAÚJO, 2005). For small farmers to obtain better financial results in marketing, one of the strategies is to eliminate as many intermediaries as possible (BLUM, 2001; KAMBARA and SHELLEY, 2002; ARAÚJO, 2005; GIUCA, 2013). The decrease in the number of intermediaries in a production chain corresponds to the so-called short marketing channel. Blanc and Kledal (2012) highlight that the distribution of fresh organic products in Brazil has been directed to short marketing channels. According to the authors, the demand for trading is expanding rapidly in organic box schemes and involves middle-class consumers, especially in large 
urban centers. Such behavior would represent a potential way to diversify the scenarios in relation to the organization of production and commercialization in regions located in the proximity of these urban centers (BLANC; KLEDAL, 2012).

The European Commission argues that farmer who accesses the short channels has advantages, such as increased revenue and job retention in rural areas, and the benefit to the local community resulting in social, economic and environmental benefits (GIUCA, 2013). The most common forms of short channels in agriculture include direct sales, e-commerce, box schemes, Community Supported Agriculture (CSA), among others (GIUCA, 2013; BELLETTI, MARESCOTTI, 2013). The CSA is considered an alternative market to promote the production of local food products that participate in this marketing system between farmers and end consumers of the product.

Consumers (or so-called co-producers) enter into an agreement with the farmer and finance the production of fruit and vegetables (conventional, organic, biodynamic, etc.) in addition to products including flowers, herbs and medicinal herbs. The farmer returns the investment made to him with the weekly supply of food baskets (ATTRA, 2006). In Brazil, this movement began in 1997 in the Northeast in a modest and timely manner. But it was in 2011 that gained strength and grew rapidly with the creation of CSA Brazil, an association that supports farmers and consumers who are interested in the principles of the CSA and help in the development of new initiatives to implement CSAs throughout Brazil (YAMAMOTO, 2006; CSA BRASIL, 2014).

The operationalization of CSA involves the transaction between farmers and consumers, being this transaction research subject from several theoretical currents, such as the New Institutional Economy (NIE) and the Transaction Cost Economics (TCE). The marketing relationship between the agents (farmer and consumer) generates transaction costs ${ }^{4}$ and according to TCE, these costs can be minimized using an appropriate governance structure (WILLIAMSON, 1985; AZEVEDO, 1997). According to Williamson (1985), the TCE allows analysis the most appropriate management structure of a transaction, through the characteristics of the agents (limited rationality and opportunism) and transactions (assets specificities, frequency and uncertainty).

Furthermore, given the scenario in which the transaction takes place, it is necessary to consider the institutional environment that influences the correct choice of governance structure that leads the actors to achieve efficiency goals (WILLIAMSON, 1985; ZYLBERSTAJN, 1995; AZEVEDO; SILVA, 2002).

Since CSA in Brazil is a recent product marketing mechanism, it is important to investigate whether the governance structure adopted by agents leads to a level of efficiency, whether for farmers or consumers. Thus, the main objective of this paper was to analyze the governance structure used in Community Supported Agriculture in the State of São Paulo, Brazil, in order to identify whether it favors coordination between agents and promotes the reduction of transaction costs. In order to achieve this objective, we sought to describe the characteristics of the institutional environment to understand the aspects that delimit the behavior of the agents and that influence in the structure of governance used between the agents, as well as to identify the characteristics of the transactions and of the agents (farmers and consumers) from the TCE's viewpoint. The selection of the State of São Paulo is justified

${ }^{4}$ Transaction cost is defined by Williamson (1985) as the cost of accessing the market. 
because it is the state that aggregates the largest number of consumers and farmers who use the CSA model for production and consumption of agricultural products in Brazil.

\section{THEORETICAL FRAMEWORK}

In order to evaluate the transaction between farmer and consumers, the theoretical framework was supported by the Transaction Cost Economics. TCE is an economic theory that emerged from a broader theoretical scope called New Institutional Economics. NIE emerged in 1937 with Ronald Coase as a reaction to the assumptions of the Neoclassical Theory about firms, because the neoclassical view supposed that there was no informational asymmetry between the agents involved in the transaction, the transaction costs being equal to zero with the existence of complete rationality of the agents (ZYLBERSZTAJN, 1995; KHERALLAH; KIRSTEN, 2001). Coase (1937) argued that it was not possible to analyze the company only as a production function conditioned to the price mechanism, as it was considered by the neoclassicals, because there is a cost to access the price system, which allows you to really discover what the prices are, negotiate, contract and monitor contracts.

The cost to which Coase referred to in 1937 was later called transaction costs. According to Ménard (2014) the transactions matter so much for NIE because they play such an essencial role in determining the possibilities to take advantage of division of labor and specialization. The firm is a set of contracts and so there is a need to study organizations as a set of rules (institutional arrangement) that governs transactions (COASE, 1937; WILLIAMSON， 1985; AZEVEDO 1997; KHERALLAH; KIRSTEN, 2001; ZYLBERSTAJN, 2005). Therefore, it was possible to study the organizations as institutional arrangements that conduct the transactions.

Thus, the form of governance of the firm could be predicted by analyzes of variables guided by institutional rules (ZYLBERSTAJN, 2005). Institutions are the "rules of the game in a society" (NORTH, 1992, p 05; 1990, p 03). According to North (1991, p.97) institutions are "the humanly invented constraints that structure political, economic, and social interaction." Humans themselves have created institutions to reduce uncertainty in exchange ratios (NORTH, 1991). The incentive structures of an economy are provided by institutions, which indicate the direction of economic change for growth, stagnation or decline (NORTH, 1990). According to the same author, institutions may have formal rules (constitutions, law, property rights) or informal rules (customs, tradition and sanctions) (NORTH, 1991). NIE evaluates the role of institutions at two analytical levels: Institutional Environment and Governance Structures (NORTH, 1991; AZEVEDO, 2000; FELTRE; PAULILLO, 2006).

The institutional environment corresponds to the set of political, social and legal rules that support the production, exchange and distribution between agents (ZYLBERSTAJN, 1995). Organizations develop within the institutional environment (NORTH, 1994). "If institutions are the rules of the game, organizations are the players" (NORTH, 1992, p.10). Organizations must meet human needs within the limits of the institutions. According to North (1994), the institutional evolution of an economy is shaped by the interaction between institutions and organizations. Institutions influence organizations and these are influenced by 
institutions. Evolution happens when institutions adapt to new forms of organizations (NORTH, 1994; 1990).

Institutional arrangements are important for framing the behavior of participants in an agro-industrial system, such as: policies of minimum prices, agrarian reform, property rights of the land, food security policies, among others (AZEVEDO; SILVA, 2002). The institutional rules can be decisive for the efficiency and competitiveness of the sector (NORTH, 1992; AZEVEDO; SILVA, 2002).

The institutional environment influences the adequacy of the governance structure related to the attributes of the transactions for the farmer to reach the efficiency objectives (WILLIAMSON, 1985; ZYLBERSTAJN, 1995; AZEVEDO; SILVA, 2002). According to Williamson (1979), the governance structure is understood as the institutional framework in which transactions are decided and its function is to minimize the transaction costs of organizations, and this analysis is based on the theory of Transaction Cost Economics (WILLIAMSON, 1985). TCE is used to evaluate the economic relationship or any other that takes the form of a contractual phenomenon (or that can be described in this way) (WILLIAMSON, 1985). Transaction costs are all costs incurred in the operation of an economic system (NORTH, 1992), and can be defined as the cost of accessing the market (WILLIAMSON, 1985). Such costs may be of the following types: ex ante (costs incurred prior to transactions) or ex post (costs incurred in maintaining the transaction) (WILLIAMSON, 1985). The structures of governance of the transactions are classified in market structure, hierarchical forms and hybrid forms (WILLIAMSON, 1985; ZYLBERSTAJN, 1995).

The market structure has as a determining variable the price, where there is no dependence between the buying and selling agents, there is no commitment to repeat the transaction in the future, and there is a high degree of incentive for the agents of the transaction. Hierarchical forms (or vertical integration) are characterized by incorporating segments of other activities within the firm, either upstream or downstream. Thus, there is flexibility to execute faster adaptations and there is a loss of incentives among the agents involved in the transactions. The hybrid forms are characterized by their agents being autonomous, but with some bilateral dependence. There is an incentive guarantee (less effective than market structure); administrative costs and safeguards are required (WILLIAMSON, 1985; ZYLBERSZTAJN, 1995).

According to Zilbersztajn (2005), formal contractual relations and long-term informal cooperation agreements are established among the agents of a system as a way of avoiding costs associated with the market and enabling an increase in the value of the organization (in so far as it reduces risks) by contractual means. Menard (2018) combines transaction cost and relational contracts models to capture a variety of representative economics forms, with the hybrids arrangements exercising important role in the agrifood industry, especially in analysis of the cooperatives and plural forms. Examples of non-standard arrangements could be networks, alliances, joint ventures, etc (MÉNARD, 2014).

The decision on which governance structure would be most appropriate for a commercial transaction, according to TCE, should be based on the analysis of the characteristics of the agents and the characteristics of the transactions. 
The characteristics of the agents have as behavioral assumptions the limited rationality and opportunistic behavior, because the TCE considers that there are intrinsic factors to its behavior that affect the transactions and imply in incomplete contracts. Limited rationality exists in a transaction since individuals are not able to predict the future scenario of a transaction, and even if there is a set of information to which the agent has access, it is not possible to interpret and process them accurately, due to the individuals' cognitive limitation (WILLIAMSON, 1985).

The second assumption, opportunism, occurs when one of the agents involved in the transaction performs attitudes to take advantage of the situation, due to limited rationality or information asymmetry. Individuals do not always have opportunistic attitudes, but when they do, there is a need for contracts and, consequently, there is a cost to safeguard the transaction (ZYLBERSZTAJN, 1995).

Regarding the characteristics of the transactions, the variables that make up the transaction dimensions are: asset specificity, frequency and uncertainty.

The asset specificity, according to Azevedo (1997), can be defined as the characteristic of an asset that represents the magnitude of its value, being dependent on the continuity of the transaction to which it is specific. This element is considered the most important in a transaction by Williamson (1985), since it relates the costs generated by the impossibility of alternative allocation of an asset in another transaction and defines six types of asset specificity: locational, physical, human resources, technological, of brand and temporal.

Locational specificity refers to the physical distance between the producer and the customer and is associated with a high transportation cost, with a condition of immobility of assets, in which the costs of installation and/ or relocation are higher (WILLIAMSON, 1985), as for example, what happens with the areas of denomination of origin (ZYLBERSZTAJN, 1995). Physical specificity refers to the cost associated with the transaction of the assets related to the characteristics of the product, such as: specific machines for an activity or a citrus orchard. It is noticed that in some cases the reallocation of the assets to produce the product can be more or less costly and even impossible (WILLIAMSON, 1985), as in the case of the citrus orchard that takes years to start producing (NEVES, 1997).

Human resources specificity of is the cost generated by the reallocation of a specific human capital to a given activity (WILLIAMSON, 1985). This specific human capital may have been accumulated by experience in the activity or by specific training and, if employed in any other way than the original, loses the value given to it (FELTRE; PAULILLO, 2006). It is considered that the technological specificity occurs when the company or producer makes an investment in an asset to attend a particular transaction (WILLIAMSON, 1985). Feltre and Paulillo (2006) use the example of soy production dedicated to the foreign market. If part of the production does not find a foreign buyer, then there will be an excess supply in the domestic market and the price of the grain will reduce considerably.

Brand specificity refers to the characteristics of a brand, i.e., the reputation which the brand built on the market (WILLIAMSON, 1985; NEVES, 1999). Temporal specificity is associated to the time in which the transaction occurs, because for certain products this time is important due to specific characteristics, such as perishability (ZYLBERSZTAJN, 1995; FELTRE; PAULILLO, 2006). 
According to Williamson $(1985,1991)$, the specificity of the asset is the most relevant element to explain the difference in transaction costs, where the efficiency of governance structures varies according to the assets specificity. As the assets specificity increases, the lower cost is represented by the hierarchical governance structure, so vertical integration is preferred. When the asset specificity is low, the structure that presents the lowest cost is the market.

In general, when it comes to the commercialization of fruits, vegetables and organic vegetables, in terms of the characteristics of the transactions, the following assets specificities exist: temporal and locational (perishability), brand (certification) and human resources (specific knowledge) (CUNHA, 2010). In addition, they are susceptible to climatic conditions (frost, drought and others).

Regarding the other characteristics of the transactions, frequency and uncertainty, the frequency is defined by the number of times that occurs a transaction (AZEVEDO; SILVA, 2002) and the uncertainty corresponds decisions regarding the modalities of arrangements chosen to procure input or deliver outputs, such as related to the market, technological factor or performance assessment (SCHNAIDER; MÉNARD; SAES, 2017) The intense frequency in relationships leads to the building of reputation and trust between the parties, which reduce the cost of transactions (AZEVEDO; SILVA, 2002). On the other hand, opportunistic behavior implies a greater degree of uncertainty, leading to higher transaction costs, mainly in renegotiations, because they will have more future adaptations in the contracts and will require a more rigorous control (NEVES, 1997). In the marketing relationships of organic products, the opportunistic behavior of a farmer may cause a consumer to acquire a product that does not contain the attributes reported by the producer, for example pesticide-free product.

In order to respond to the objective of this research, which is to analyze the governance structure used by the CSAs of the state of São Paulo, analyzes of the characteristics of the agents and of the transactions will be carried out from the viewpoint of farmers and consumers.

\section{MATERIAL AND METHODS}

The present study is characterized as an applied research, with a descriptive character, following a qualitative-quantitative approach. According to Gil (2002), the research is descriptive when it is intended to describe the characteristics of a phenomenon / population or to seek relationships between the variables, and its main characteristic is the collection of data through questionnaire or systematic observation. Knechtel (2014, p. 106) guides the quantitative study "when the researcher is interested in dimensioning and evaluating the application of a technique or the introduction of a variable", and the qualitative research when it intends "to observe the phenomenon, to understand it or to comprehend it in an integral way" (KNECHTEL, 2014, p.106).

The research method adopted was the survey, because according to Freitas et al. (2000), the survey is used when the research wants to answer questions such as: "what?",

DRd - Desenvolvimento Regional em debate (ISSNe 2237-9029) 
"why?", "how much?" and the object of interest is in the present or in the recent past. The data collection tool used was questionnaires addressed to farmers and consumers. The data collection was obtained by a cross-sectional and the unit of analysis was CSA Brazil ${ }^{5}$, an Association established in 2013 to support CSA initiatives.

In the period when this research was formulated, in the first quarter of 2015, CSA Brazil had 21 municipalities with CSAs in operation, 14 in the state of São Paulo, 2 in Minas Gerais and 1 in each of the following states: Rio de Janeiro, Rio Grande do Sul, Paraná, the Federal District and Pernambuco. The number of farmers linked to CSAs in the country was 16, 12 in the state of São Paulo, 3 in Minas Gerais and 1 in Rio Grande do Sul.

It was decided to delimit the scope of the object of study in the state of São Paulo, because it contains the largest number of CSAs and a greater number of members, besides being the state where the activities linked to the CSA Brazil were initiated (CSA Demétria in Botucatu/SP).

In order to collect the data it was necessary to contact the farmer to identify the CSA to which he supplied products and the number of consumers of the unit in which he served. The sample of farmers was established according to the convenience sampling technique. Data regarding the number of consumer families served by the farmers of the CSAs surveyed generated the amount of 875 consumer families linked to the CSAs of the state of São Paulo (December 2015 and January 2016). Thus, considering a sample error risk of 5\% and a 90\% confidence level, a representative sample of the State of São Paulo would need to contain at least 207 families $^{6}$. Therefore, a sample with 207 families represented $23.65 \%$ of the total, so the stratified $^{7}$ proportional sampling technique for consumers in each CSA and this percentage of consumer families was withdrawn to compose the sample in each CSA. It should be noted that the response of one member per family was considered.

Data collection took place between the months of December 2015 and January 2016. Data collection with farmers and consumers was carried out through interviews and through questionnaires, which were sent by electronic mail. Finally, the sample of farmers was composed of 11 agents, who represented $91.6 \%$ of the farmers' population. Data were collected from farmers and consumers of 12 CSAs, representing $85.7 \%$ of CSA units in the state of São Paulo. The sample of consumer families had 241 observations.

In order to achieve the research objective, (analyze the governance structure used in Community Supported Agriculture in the State of São Paulo, Brazil, in order to identify whether it favors coordination between agents and promotes the reduction of transaction costs), an extensive theoretical review on ECT and a bibliographic review on CSA-related activity were carried out to define the variables that should compose the scale. Thus, the questions that evaluated the characteristics of the transactions and the agents were elaborated according to the TCE literature and for the answers the five-level Likert scale was used, which varied of no importance (1) even very important (5). The levels (low, medium and

\footnotetext{
${ }^{5}$ The CSA Brazil Association has a website where it is possible to identify the location of CSAs in Brazil, as well as to obtain information about CSA training courses and projects developed by CSA. On this site a survey of secondary data was carried out.

${ }^{6}$ The formula used to calculate the sample size (n) was: $n=\frac{N \cdot Z^{2} \cdot p \cdot(1-p)}{Z^{2} \cdot p \cdot(1-p)+e^{2} \cdot(N-1)}$

${ }^{7}$ The stratified proportional sampling method seeks to collect proportionally the same amount of elements (consumers) in all extracts (CSAs) and thus it is possible to obtain statistical significance for the sample.
}

DRd - Desenvolvimento Regional em debate (ISSNe 2237-9029) 
high) that measure the intensity of the transaction and agent characteristics were created according to the scale presented in Table 1.

The characteristics of the agents were measured according to the level of opportunism and limited rationality. The variables that made up the analysis of opportunism were production management, product quality, diversity of products offered, quantity consumed, production volume forecast, future prices forecast, production improvements and improvements to the delivery system. In order to analyze the limited racionality among the agents, the variables were used to measure the degree of risk of non-compliance with consumer were: market price is more advantageous than the combined, lack of payment for some consumers, lower volume produced, low variety in production, no longer holds of the certificate and do not deliver the products for pest or weather reasons.

The transaction characteristics were analyzed based on the degree of asset specificity, of the frequency and uncertainty. The variables used to analyze the assets specificity factor were locational, temporal, physical, human resources, technological and brand specificities. The variables used to analyze the uncertainty factor were the importance degree of the agreement (formal or informal) for: keep trading with CSA; keep the price deal entre os agents, be sure to receive the monthly payment, ensure production and marketing to the CSA consumer. And finally, the variables used to analyze the frequency factor were relationship length and transaction frequency.

Table 1 - Scale of levels adopted by the survey to measure the intensity of transaction and agent characteristics

\begin{tabular}{|c|c|c|c|c|}
\hline & & Low level & Medium level & High level \\
\hline \multirow[t]{2}{*}{$\begin{array}{c}\text { Agents } \\
\text { Characteristics }\end{array}$} & $\begin{array}{l}\text { Limited } \\
\text { rationality }\end{array}$ & Always / sometimes & Few times & $\begin{array}{l}\text { Rarely / no change } \\
\text { information / } \\
\text { occasions }\end{array}$ \\
\hline & Opportunism & Impossible / Low & Medium & Very high / high \\
\hline \multirow{5}{*}{$\begin{array}{c}\text { Transaction } \\
\text { Characteristics }\end{array}$} & Asset specificity & $\begin{array}{l}\text { No importance and } \\
\text { few importance }\end{array}$ & Indifferent & $\begin{array}{l}\text { Very important / } \\
\text { important }\end{array}$ \\
\hline & Uncertainty & $\begin{array}{l}\text { No importance and } \\
\text { few importance }\end{array}$ & Indifferent & $\begin{array}{l}\text { Very important / } \\
\text { important }\end{array}$ \\
\hline & Frequency & & & \\
\hline & $\begin{array}{l}\text { Length of } \\
\text { relationship }\end{array}$ & $\begin{array}{l}\text { Less than } 6 \text { months / } \\
6 \text { to } 12 \text { months }\end{array}$ & 12 to 18 months & $\begin{array}{l}18 \text { to } 24 \text { months / } \\
\text { more than } 24 \text { months }\end{array}$ \\
\hline & $\begin{array}{l}\text { Transaction } \\
\text { frequency }\end{array}$ & Once a week & $\begin{array}{l}\text { Once every } 15 \\
\text { days }\end{array}$ & Once a month \\
\hline
\end{tabular}

Source: prepared by the authors

A bibliographic review was also carried out in order to identify the legal factors that impact the production and consumption systems linked to a CSA.

Data analysis was performed in three stages. The first step was to describe the characteristics of the institutional environment. In the second stage, it was possible to characterize the agents, through a descriptive analysis. In the last stage of the analysis, the 
characteristics of the transactions and the characteristics of the agents were aligned, thus understanding the governance structure used.

\section{RESULTS}

The results are divided into five sections: the first one brings the profile of farmers and consumers associated to CSAs of the state of São Paulo, as a way to understanding the broader research context; in section 4.2 presents the analysis of the institutional environment in which the Brazilian CSAs are inserted; in section 4.3 the characteristics of agents and transactions are presented from the perspective of farmers. Then, section 4.4 brings the characteristics of agents and transactions from the perspective of consumers and section 4.5 finalizes the results with the analysis of the governance structure used.

\subsection{CHARACTERIZATION OF FARMERS AND CONSUMERS LINKED TO THE CSAS OF THE STATE OF SÃO PAULO}

The study made it possible to examine the profile of farmers and consumers associated with the CSAs of the State of São Paulo and the CSA model used. Farmers participating in the survey are family farmers 8 , predominantly men; $63.6 \%$ of the properties destined for production are private and $45.5 \%$ derive their income exclusively from marketing with the CSA. According to farmers, marketing with the CSA was motivated by environmental factors, proximity to the consumer and place of delivery, ideological reasons, lower financial risk and the ease of selling.

With regard to the characteristics of the products, they are organic or biodynamic, with almost all products being vegetables; $27.3 \%$ of farmers carry out food processing to be marketed by the CSA. It was found that $54.4 \%$ of farmers have the certificate of producer obtained through the Participatory System of Guarantee ${ }^{9}$ (PGS), 45.5\% of farmers drive less than 10 kilometers to deliver the products to the delivery point and another $45.5 \%$ travel from 11 to 50 kilometers.

The consumers who took part in the survey were members of each family associated with the CSA. Analysis of the profile showed that $78.8 \%$ were women; $61.1 \%$ said they were responsible for purchasing food in their homes; $45.5 \%$ of respondents had completed

\footnotetext{
${ }^{8}$ According to Brazilian Law No. 11,326 of July 24, 2006, the farmer is classified as a family member when practicing activities in rural areas and meets the requirements simultaneously: does not have an area larger than four fiscal modules, predominantly uses family labor in the activities of the establishment, has a minimum percentage of income from the economic activities developed in the establishment and runs its establishment with the family.

${ }^{9} \mathrm{PGS}$ is an organic conformity assessment mechanism recognized by SISORG and used by producers registered with Participatory Conformity Assessment Organizations (OPACs by its acronym in Portuguese), accredited by MAPA. The PGSs have organic conformity assessment commission composed of producers, processors, consumers, technicians, among others.
}

DRd - Desenvolvimento Regional em debate (ISSNe 2237-9029)

V. 11, p. 48-70, 2021. 
university studies and $57.8 \%$ said that the monthly family income was higher than 8 minimum wages; $51.2 \%$ of respondents had been involved in marketing between agents for less than a year. Vegetables from the CSA provide more than $76 \%$ of the total number of these foods consumed in the residence of $47 \%$ of consumers.

\subsection{INSTITUTIONAL ENVIRONMENT ANALYSIS}

An analysis of the institutional environment is important in this research because the choice of governance structure used by a marketing channel is influenced by the institutional environment (CUNHA, 2010). According to Zylberstajn (1995), the institutional environment consists of set of political, social and legal rules that support production, exchange and distribution between agents. Therefore, the formal rules associated with marketing direct channel of organic and biodynamic products, specifically the CSA, are the laws that regulate the activity. We can signal the Brazilian legislation for organic certifications, whose role of the State extends from the regulation and supervision of the sector, as well as the accreditation of certifiers, and also provide exemption from the need for organic certification for some farmers (BRASIL, 2006, Id. 2003).

The farmers in this research use the certification and certification exemption resources. Law No. 10,831 of December 23, 2003 guarantees that certification is unnecessary, since the sale of the organic product is carried out by a family farmer linked to a social control organization (BRASIL, 2003).

Informal rules are the behavioral norms of the agents involved in the channel, the culture of consumers and farmers, the values of those involved and ideological motives. Some producers market their products under the "biodynamic" brand, and although Brazilian legislation considers that this type of management is part of the concept of an organic production system and is subject to the same regulation (BRASIL, 2003), the biodynamic products are part of an international ecological network and must be certified by the Demeter label. Therefore, there is an informal rule associated with the commercialization of the product. The association Demeter International developed the standards for biodynamic production and the certification of a production in Brazil is issued by the Brazilian Association of Biodynamic Agriculture or by the company IBD certifications.

The other informal rules on the marketing channel in which the CSA is inserted involve intangible factors. These factor my be mentioned: the culture and values of farmers and consumers, ideological reasons (associated with the associative economy) and the practice of sustainable, environmentally friendly extraction.

In connection with the marketing between farmers and consumers associated with the CSA, there is an important organization, CSA Brazil. CSA Brazil is a non-profit association whose mission is to support CSA initiatives, provide information about the CSA and promote the movement in the media. The association acquires resources through donations and membership fees. The association fee is approximately $\mathrm{R} \$ 5.00$ per month (for the year 2015) and is charged to consumers associated with CSA Brazil. Payment of this fee is optional, and in 2015 only four CSAs contributed to the amount. Regardless of payment of the fee, farmers

DRd - Desenvolvimento Regional em debate (ISSNe 2237-9029) 
connected to the CSA and the unit itself receive instructions and technical visits on request. The association does not monitor the units related to the principles used, the price that are in the shopping cart.

Most CSAs have organizers responsible for paying the monthly fee (paid in advance), defining and organizing an accessible delivery point for consumers, the communication link between farmers and consumers to exchange information on production forecasts, consumer and farmer satisfaction.

\subsection{CHARACTERISTICS OF FARMERS AND TRANSACTIONS}

This section aims to assess the characteristics of transactions and agents according to the perception of farmers. Table 2 summarizes the results found for agents and transaction characteristics, according to the perception of farmers. 
Analysis of the community supported agriculture model in Brazil from the point of view of the transaction cost economic

Table 2 - Summary of agent characteristics and transactions of farmers associated with the CSAs of the State of São Paulo.

\begin{tabular}{|c|c|c|c|c|}
\hline \multirow{3}{*}{ 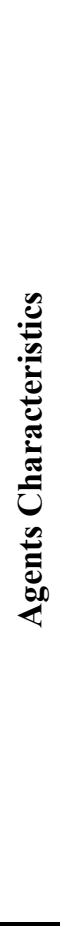 } & & Low level & $\begin{array}{c}\text { Medium } \\
\text { level }\end{array}$ & High level \\
\hline & $\begin{array}{l}\text { Limited rationality in relation to: } \\
\text { Social relations with consumers } \\
\text { Information Exchange in relation to: } \\
\text { Production management } \\
\text { Product quality } \\
\text { Diversity of products offered } \\
\text { Quantity consumed } \\
\text { Production volume forecast } \\
\text { Future prices forecast } \\
\text { Production improvements } \\
\text { Improvements to the delivery system }\end{array}$ & $\begin{array}{l}63.6 \% \\
72.7 \% \\
81.8 \% \\
90.9 \% \\
72.7 \% \\
72.7 \% \\
45.5 \% \\
81.8 \% \\
54.5 \% \\
\end{array}$ & $\begin{array}{r}27.3 \% \\
\\
18.2 \% \\
18.2 \% \\
9.1 \% \\
18.2 \% \\
9.1 \% \\
18.2 \% \\
9.1 \% \\
9.1 \% \\
\end{array}$ & $\begin{array}{r}9.1 \% \\
\\
9.1 \% \\
0 \% \\
0 \% \\
9.1 \% \\
18.2 \% \\
36.3 \% \\
9.1 \% \\
36.4 \%\end{array}$ \\
\hline & $\begin{array}{l}\text { Opportunism * } \\
\text { Degree of risk of non-compliance with consumer: } \\
\text { Market price is more advantageous than the combined } \\
\text { There is a lack of payment from some consumers } \\
\text { There is less volume produced } \\
\text { There is little variety in its production } \\
\text { No longer holds of the certificate } \\
\text { For pest or weather reasons do not deliver the products }\end{array}$ & $\begin{array}{r}100 \% \\
90.9 \% \\
63.6 \% \\
81.8 \% \\
100 \% \\
63.6 \% \\
\end{array}$ & $\begin{array}{r}0 \% \\
9.1 \% \\
27.3 \% \\
18.2 \% \\
0 \% \\
36.4 \%\end{array}$ & $\begin{array}{r}0 \% \\
0 \% \\
9.1 \% \\
0 \% \\
0 \% \\
0 \%\end{array}$ \\
\hline \multirow{3}{*}{ 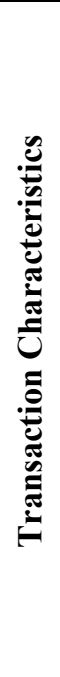 } & $\begin{array}{l}\text { Asset specificities } \\
\text { Locational } \\
\text { Temporal } \\
\text { Physical } \\
\text { Human Resources** } \\
\text { Technological** } \\
\text { Brand }\end{array}$ & $\begin{array}{r}0 \% \\
0 \% \\
18.2 \% \\
18.2 \% \\
0 \% \\
18.2 \% \\
\end{array}$ & $\begin{array}{r}18.2 \% \\
0 \% \\
9.1 \% \\
0 \% \\
0 \% \\
0 \%\end{array}$ & $\begin{array}{r}81.8 \% \\
100 \% \\
72.7 \% \\
81.8 \% \\
100 \% \\
81.8 \%\end{array}$ \\
\hline & $\begin{array}{l}\text { Uncertainty * } \\
\text { Importance Degree of the agreement (formal or informal) for: } \\
\text { Keep trading with CSA } \\
\text { Keep the price agreement with the consumer } \\
\text { payment security } \\
\text { Ensure the production and delivery of products }\end{array}$ & $\begin{array}{r}9.1 \% \\
9.1 \% \\
0 \% \\
0 \%\end{array}$ & $\begin{array}{l}0 \% \\
0 \% \\
0 \% \\
0 \%\end{array}$ & $\begin{array}{r}90.9 \% \\
90.9 \% \\
100 \% \\
100 \%\end{array}$ \\
\hline & $\begin{array}{l}\text { Frequency } \\
\text { Length of relationship } \\
\text { Transaction frequency }\end{array}$ & $\begin{array}{r}55.0 \% \\
0 \% \\
\end{array}$ & $\begin{array}{r}27.0 \% \\
0 \% \\
\end{array}$ & $\begin{array}{r}18.0 \% \\
100 \% \\
\end{array}$ \\
\hline
\end{tabular}

\footnotetext{
* Some questions that also measure the dimension are not included in this framework, as they are dichotomous questions.

** Another variable was taken into account for the analysis of these variables: whether the investment was in the acquisition of knowledge (personnel) or technology (technology).

Notes:

Limited rationality: low level (always / sometimes), medium level (a few times), high level (rarely / no change of information / events).

Opportunism: low level (impossible / low), medium level (medium), high level (very high / high).

Asset specificity and uncertainty: low level (no importance and minor importance), medium level (indifferent), high level (very important / important).

Frequency: relationship period; low level (less than 6 months / 6 to 12 months), medium level (from 12 to 18 months), high level (from 18 to 24 months / more than 24 months) and frequency of transaction; high level (once a week), medium level (once every 15 days), low level (once a month).

Source: prepared by the author based on the research data.
} 
The data presented in Table 2 suggest there is a low limited rationality in the perception of farmers, because there is a relationship and communication between the actors that facilitates the prediction of the future scenario of the transaction. According to the literature, as smaller the limited rationality, less adaptation should be made in contracts, because farmers will be able to maximize their actions and predict future events.

To identify the opportunistic characteristics of the farmer agent, questions relating to the attitudes of self-interest / benefit of the consumer and the farmer have been used. As shown in Table 2, there is a low level of opportunism in various circumstances, especially when the market price is more advantageous than the combined price and the farmer is no longer in possession of the certificate. The fact that the farmer shows a low level of opportunism reflects ethical attitude in the renegotiation of contracts and there is a lower chance of the farmer imposing losses on the consumer.

The transaction characteristic for the asset specificity dimension shows a high specificity in all variables examined (spatial, temporal, physical, human, technological and brand-specific), i.e. a high level of investment specificity indicates the farmer is exposed to a high loss of return on his products if consumers do not comply with the combined product because the product purchased cannot easily be attributed to other consumers.

With regard to uncertainty, an attempt is made to verify how much the agreement (formal or informal) is necessary to build trust between the agents, in the perception of the farmer. The greater the importance attached to certain parts of the agreement, the greater the uncertainty that would exist to comply with it. In Table 2, it is possible to observe the high percentage of high uncertainty, because in the perception of the farmer the agreement / contract is incomplete.

The characteristic of transaction frequency identifies the relapses in transactions. It is worth noting the units of the CSAs studied have different operating times and the involvement of farmers with a recent connection to the CSA units has a higher proportion. Therefore, an assessment of the transaction characteristic would lead to a fragile conclusion only with the variable connection time. It is necessary to consider the frequency in which the transaction takes place, which refers to how often the relationship occurs over a period of time, and according to the farmers surveyed, the frequency of the transaction occurs weekly. Taking into account a weekly repetition over several months, it is reasonable to say that there is evidence that these many transactions lead to an increase in the reputation of the farmer vis-àvis the consumer.

\subsection{CHARACTERISTICS OF CONSUMER AGENTS AND TRANSACTIONS}

This section assesses the characteristics of transactions and agents according to consumer perception. Table 3 summarizes the information collected by consumers about their perception of agents and transaction characteristics.

DRd - Desenvolvimento Regional em debate (ISSNe 2237-9029) 
Analysis of the community supported agriculture model in Brazil from the point of view of the transaction cost economic

Table 3 - Summary of the characteristics of stakeholders and transactions of consumers in connection with the CSAs of the State of São Paulo.

\begin{tabular}{|c|c|c|c|c|}
\hline \multirow{4}{*}{ 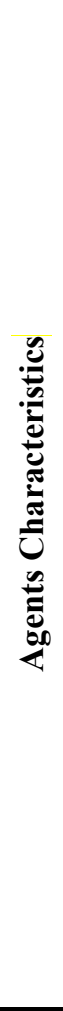 } & & $\begin{array}{l}\text { Low } \\
\text { level }\end{array}$ & $\begin{array}{c}\text { Medium } \\
\text { level }\end{array}$ & $\begin{array}{l}\text { High } \\
\text { level }\end{array}$ \\
\hline & $\begin{array}{l}\text { Limited rationality in relation to: } \\
\text { Social relations with farmers } \\
\text { Information Exchange in relation to: } \\
\text { Production management } \\
\text { Product quality } \\
\text { Diversity of products offered } \\
\text { Quantity consumed } \\
\text { Production volume forecast } \\
\text { Future prices forecast } \\
\text { Production improvements } \\
\text { Improvements to the delivery system }\end{array}$ & $\begin{array}{l}43.6 \% \\
19.5 \% \\
25.8 \% \\
32.0 \% \\
21.1 \% \\
16.2 \% \\
13.7 \% \\
17.4 \% \\
16.2 \%\end{array}$ & $\begin{array}{l}19.4 \% \\
16.6 \% \\
20.7 \% \\
17.4 \% \\
16.2 \% \\
16.2 \% \\
14.9 \% \\
18.7 \% \\
17.8 \%\end{array}$ & $\begin{array}{l}37.0 \% \\
63.9 \% \\
53.5 \% \\
50.6 \% \\
62.7 \% \\
67.6 \% \\
71.4 \% \\
63.9 \% \\
66.0 \%\end{array}$ \\
\hline & $\begin{array}{l}\text { Opportunism }{ }^{*} \\
\text { Degree of risk of non-compliance with farmers: }\end{array}$ & 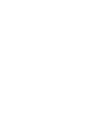 & & \\
\hline & $\begin{array}{l}\text { Market price is more advantageous than the combined } \\
\text { There is a lack of payment to some producers } \\
\text { There is less volume produced } \\
\text { There is little variety in its production }\end{array}$ & $\begin{array}{l}84.2 \% \\
86.3 \% \\
80.9 \% \\
70.5 \% \\
\end{array}$ & $\begin{array}{l}11.6 \% \\
11.2 \% \\
15.8 \% \\
20.3 \% \\
\end{array}$ & $\begin{array}{l}4.2 \% \\
2.5 \% \\
3.4 \% \\
9.2 \%\end{array}$ \\
\hline \multirow{3}{*}{ 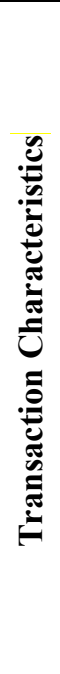 } & $\begin{array}{l}\text { Asset specificities } \\
\text { Locational } \\
\text { Temporal } \\
\text { Physical } \\
\text { Human Resources }^{* *} \\
\text { Technological }^{* *} \\
\text { Brand }\end{array}$ & $\begin{array}{l}2.8 \% \\
1.6 \% \\
3.7 \% \\
5.8 \% \\
25.7 \% \\
19.9 \%\end{array}$ & $\begin{array}{r}6.7 \% \\
5.4 \% \\
12.5 \% \\
17.0 \% \\
28.7 \% \\
28.6 \% \\
\end{array}$ & $\begin{array}{l}90.5 \% \\
93.0 \% \\
73.8 \% \\
77.2 \% \\
45.6 \% \\
51.5 \%\end{array}$ \\
\hline & $\begin{array}{l}\text { Frequency } \\
\text { Length of relationship } \\
\text { Transaction frequency }\end{array}$ & $\begin{array}{c}51.2 \% \\
0 \%\end{array}$ & $\begin{array}{c}15.2 \% \\
0 \%\end{array}$ & $\begin{array}{c}33.6 \% \\
100 \% \\
\end{array}$ \\
\hline & $\begin{array}{l}\text { Uncertainty } \\
\text { Importance Degree of the agreement (formal or informal) for: } \\
\text { Keep trading with CSA } \\
\text { Keep the price agreement with the farmer } \\
\text { Payment security to farmer } \\
\text { Ensure that the producer delivers the products }\end{array}$ & $\begin{array}{l}8.6 \% \\
7.6 \% \\
4.9 \% \\
3.8 \%\end{array}$ & $\begin{array}{l}10.8 \% \\
10.3 \% \\
9.7 \% \\
8.6 \%\end{array}$ & $\begin{array}{l}80.6 \% \\
82.1 \% \\
85.5 \% \\
87.6 \%\end{array}$ \\
\hline
\end{tabular}

\footnotetext{
* Some questions that also measure dimension are not included in this framework, as they are dichotomous questions.

** Another variable was taken into account for the analysis of these variables: "whether the investment was in the acquisition of knowledge (personnel) or technology (technology)."

Source: Prepared by the author based on the research data.
}

For the limited rationality of the intermediary, questions have been developed to assess whether there is contact and exchange of information between the consumer and the farmer to determine whether the consumers have sufficient information about the transaction in question. Table 3 shows the percentage of answers at each level, and although there is evidence of a social relationship between the intermediaries, there is no exchange of

DRd - Desenvolvimento Regional em debate (ISSNe 2237-9029) 
information about production, which indicates a high limited rationality, resulting in incomplete contracts that need to be adapted to protect the interests of consumers, for example, it will be difficult for the farmer to establish a product range that satisfies both consumers and pricing.

The opportunistic behavior of the consumer is measured by the risk of the consumer not fulfilling his obligation to the (farmer) of the CSA in the face of certain situations that may arise. As shown in Table 3, a low level of opportunism prevails for various assumed circumstances. The low level of opportunism leads to a lower number of adequacy problems related to the incompleteness of contracts. Due to limited rationality, there are incomplete contracts and these require future renegotiations (FARINA; AZEVEDO; SAES, 1997). Since the opportunism recorded in the transaction between CSA agents is low (in the perception of the consumer), the likelihood of unethical attitudes leading to losses for the other agent in the renegotiation is low (in the perception of the consumer).

The characteristic of the transaction, investment specificity, is intended to capture how much the consumer considers fixed assets important and whether there is investment to acquire them. Table 3 summarizes all the variables used to measure this characteristic. It is possible to observe a high specificity in consumer perception of most variables, indicating a greater dependence on the relationship between the consumer and the farmer.

The uncertainty feature was assessed on the basis of questions aimed at assessing how much uncertainty there is in the performance of the contract from the perspective of consumers by the actors participating in the CSAs. Table 3 summarizes that uncertainty in the perception of consumers arises due to the strong importance attached to the agreement, although consumers have no reason to do so because the occurrence of opportunistic attitudes by the farmer does not exist.

The characteristic of the frequency transaction evaluates how long the consumer has been a member of the CSA and how often the transaction has taken place. In Table 3, it can be noted the largest proportion of the consumers surveyed have recently signed up to the CSA (less than 12 months), but the frequency with which the transaction takes place is high (once a week). In view of this scenario, there is evidence of a high frequency of transactions. In the literature, it is possible to verify that if the frequency of transactions recurs, there is a scenario of increasing the level of trust among intermediaries, as reputation is constructed, which implies lower transaction costs. Contracts, whether formal or informal, would therefore no longer be important.

\subsection{ANALYSIS OF THE GOVERNANCE STRUCTURE}

The sub-topics analyzed in the preceding sections provided data to evaluate the governance structure used in the transaction. Table 4 was designed to summarize information on the characteristics of transactions and agents for analysis of alignment considering all survey participants. 
Analysis of the community supported agriculture model in Brazil from the point of view of the transaction cost economic

Table 4 - Alignment of characteristics of transactions and agents

\begin{tabular}{|c|c|c|c|c|c|c|}
\hline & \multicolumn{3}{|c|}{ Farmer } & \multicolumn{3}{|c|}{ Consumer } \\
\hline & $\begin{array}{l}\text { Low } \\
\text { level }\end{array}$ & $\begin{array}{l}\text { Medium } \\
\text { level }\end{array}$ & $\begin{array}{l}\text { High } \\
\text { level }\end{array}$ & $\begin{array}{l}\text { Low } \\
\text { level }\end{array}$ & $\begin{array}{c}\text { Medium } \\
\text { level }\end{array}$ & $\begin{array}{l}\text { High } \\
\text { level }\end{array}$ \\
\hline \multicolumn{7}{|l|}{ Asset specificities } \\
\hline Locations & & & $\mathbf{X}$ & & & $\mathbf{X}$ \\
\hline Temporal & & & $\mathbf{X}$ & & & $\mathbf{X}$ \\
\hline Physical & & & $\mathbf{X}$ & & & $\mathbf{X}$ \\
\hline Human Resources & $\mathbf{X}$ & & & $\mathbf{X}$ & & \\
\hline Thecnological & & & $\mathbf{X}$ & & $\mathbf{X}$ & \\
\hline Brand & & & $\mathbf{X}$ & & & $\mathbf{X}$ \\
\hline Frequency & & & $\mathbf{X}$ & & & $\mathbf{X}$ \\
\hline \multicolumn{7}{|l|}{ Uncertainty } \\
\hline Importance Degree of the agreement & & & $\mathbf{X}$ & & & $\mathbf{X}$ \\
\hline Breach of agreement & & & $\mathbf{X}$ & $\mathbf{X}$ & & \\
\hline \multicolumn{7}{|l|}{ Limited rationality } \\
\hline Social relations with farmers & $\mathbf{X}$ & & & $\mathbf{X}$ & & \\
\hline \multicolumn{7}{|l|}{ Information Exchange in relation to: } \\
\hline $\begin{array}{l}\text { Production management, Product quality, } \\
\text { Diversity of products, Quantity consumed, } \\
\text { Production volume forecast, Production } \\
\text { improvements, Improvements to the delivery } \\
\text { system }\end{array}$ & $\mathbf{X}$ & & & & & $\mathbf{X}$ \\
\hline Future prices forecast & & $\mathbf{X}$ & & & & $\mathbf{X}$ \\
\hline Opportunism & $\mathbf{X}$ & & & $\mathbf{X}$ & & \\
\hline
\end{tabular}

Source: Prepared by the author from the research data.

It is possible to observe two misaligned items. As for the characteristic of transactions, there is technological specificity and uncertainty (breach of agreement), and as for the characteristic of agents, limited rationality (exchange of information). The other characteristics are at the same level, and differ from each other by the degree of agreement.

Thus, it was possible to identify a positive scenario for the relationship, with no opportunistic attitudes in the agents' perception. Limited rationality converges in the perceptions of farmers and consumers for the analysis of the social relationship variable. Reinforcing the analysis of the characteristics of agents and transactions, there are informal aspects, since there is the sharing of values between agents as ideological issues (associated with the associative economy) and the practice of sustainable, environmentally friendly extraction, which reduces the opportunism of both parties. However, it should be noted that there are some formal mechanisms, such as organic certification and the existence of the consumer association, CSA Brasil, which reinforces the high specificity of the assets.

The sub-topics analyzed in the preceding sections provided data to evaluate the governance structure used in the transaction. The assessed scenario shows that the specified governance structure is the hybrid - with the bilateral dependence between autonomous actors, as currently occurs according to Williamson (1985), being one. In this form of governance, the actors consider conflicts that occur during the contract to be resolved in a common way. There are some specific features of the hybrid governance structure for the CSA in Brazil, including: the difficulty finding a supplier (farmer) due to the complexity of the production

DRd - Desenvolvimento Regional em debate (ISSNe 2237-9029) 
process and product quality requirements. Due to the bilateral dependence between actors, the formal or informal contract is used to ensure that their needs are met.

The TCE theory has been used to identify the governance that generates better efficiency according to the characteristics of the transactions and the agents. Thus, it is possible to determine that the governance structure adopted by the CSA agents favors coordination and reduces transaction costs. However, there are gaps in this structure that contribute to risks for both the farmer and the consumer. Measures to reduce uncertainty and increase the exchange information should be considered to reduce the risks of the transaction.

Furthermore, an adjustment is proposed that would reduce the uncertainty of the farmer by creating an element in the agreement between the parties that, for example, sets a minimum commitment period of four months by the consumer. Consumers are predisposed to make payments in advance (in season), and the study found $57.0 \%$ of respondents in this study would remain tied to the CSA by paying in advance for the season, and $36.5 \%$ of consumers replied this may be the case.

\section{CONCLUSIONS}

The present study analyzed the marketing mechanism known as Community Supported Agriculture, characterized as a short food supply channel. The problem that prompted the research was to identify the governance structure used in analyzing the characteristics of transactions and stakeholders.

The institutional environment in which the CSAs are integrated confirms the efficiency of transactions between the actors, as the activity is regulated by standards for the production and marketing of organic products. In addition, an informal organization supports the actors (CSA Brazil), which promotes training, discussion and the strengthening of this marketing model.

The transaction of the products analyzed is carried out between farmers and consumers to obtain organic and biodynamic food baskets. This transaction takes place within the framework of an alternative market movement and can be influenced by exogenous variables including ecological, social and cultural motivations. Thus, to achieve the objective of analyzing the governance structure used in the transaction between farmers and consumers, it was necessary to identify the characteristics of transactions and agents.

In the perception of farmers, the characteristics of the transactions showed a high degree of local, temporal, physical, brand and technological specificity. The frequency of transactions is recurring, and they take place in an environment of uncertainty, as there is a breach (informal or formal) of contract on the part of consumers and the contract is given high importance (informal or formal). Although the transaction is frequent and creates reputation and trust among the actors, the uncertainty factor leads to the need for a contract with guarantees to protect interests.

DRd - Desenvolvimento Regional em debate (ISSNe 2237-9029) 
If the characteristics of the actors are analyzed from the perspective of the farmers, opportunistic behavior is low and there is a high level of social relations and information exchange. Information exchange takes place according to aspects of production, product quality, consumption, forecast, volume and improvements in the delivery system. Farmers stated that there is an average level of information exchange only for the future aspect of the price forecast.

The analysis of the characteristics of the transactions from the perspective of the consumers showed the specifics of the assets (location, time, physical and brand-specific) and the frequency of transactions are relevant. Social relations are regularly established and there is no opportunistic behavior of farmers. Consumers have shown importance for the agreement, but do not consider it necessary to use it for transaction processing. Limited rationality is high for the aspect of information exchange that harms the farmer in terms of predicting future scenarios. Security measures are required in the agreement to reduce uncertainty and create a mechanism for permanent information exchange between agents, as consumers are faced with an uncertain environment, with a high limited rationality in terms of the transaction.

With regard to the above-mentioned characteristics, it can be concluded the governance structure specified and actually used in the transaction is a hybrid with bilateral dependence, which favors coordination and reduces transaction costs, the needs of the actors are guaranteed by formal or informal contracts. It should be stressed that the contracts (formal or informal) are incomplete with regard to the uncertainty of the transaction. Therefore, a possible adjustment, which reduces uncertainty between the parties, can contribute to the risk reduction of the transaction by creating an element in the agreement that establishes a minimum binding period for the consumer.

This research sought to contribute to the application of the TCE theory, and to analyze the relationship of commercialization between agents linked to the CSAs in the State of São Paulo, besides contributing to the characterization of the agents involved in the movement (CSA) and the properties destined for production. In addition, it enables understanding of a commercial transaction between producer and consumer that can be improved, bringing implication for other aspects, such as social ties and better well-being in food.

The TCE theory has been used to identify the governance structure that generates better efficiency according to the characteristics of the transactions and stakeholders. Thus, it is possible to determine that the governance structure adopted by the CSA representatives favors coordination and reduces transaction costs. However, there are gaps in this structure that pose risks to both the farmer and the consumer. Measures to reduce uncertainty and increase information exchange should be on the agenda of discussions to reduce the risks associated with the transaction.

\section{Disclosure statement}

No potential conflict of interest was reported by the authors. 


\section{REFERENCES}

ARAÚJO, M. J. Fundamentos de agronegócio. São Paulo: Atlas. 2005.

ATTRA. National Sustainable Agriculture Information Service. 2006. Disponível em: $<$ https://attra.ncat.org $>$. Acesso em: 02 ago. 2015.

AZEVEDO, P. F. "Economia dos Custos de Transação". Competitividade: mercado, estado e organizações, p. 71-109, 1997.

AZEVEDO, P. F. "Nova Economia Institucional: referencial geral e aplicações para a agricultura". Revista agricultura, v.1, p. 33-52, 2000.

AZEVEDO, P. F.; SILVA, V. L. "Franquias de alimentos e coordenação de cadeias agroindustriais: uma análise empírica". Revista de Administração, v. 37, p.51-62, 2002.

BELLETTI, G.; MARESCOTTI, A. "The Economic Innovation of the short chain”. In: GIARÈ, F.; GIUCA, S. (Ed.). Farmers and short chain: Legal profiles and sócio-economic dynamics. Rome: Instituto Nazionale di Economia Agrária (INEA), 2013. p. 43-57

BLANC, J.; KLEDAL, P. R. "The brazilian food sector: prospects and constraints of facilitating the inclusion of smallholders". Journal of Rural Studies, v. 28, p. 142-154, 2012.

BLUM, R. "Agricultura familiar: Estudo preliminar da definição, classificação e problemática". Agricultura familiar realidades e perspectivas, p. 57-104, 2001.

BRASIL. Regularização da Produção Orgânica. Ministério da Agricultura: Brasília, Disponível em: $<$ http://www.agricultura.gov.br/desenvolvimentosustentavel/organicos/legislacao>. 2003. Acesso em: 03 set. 2015.

BRASIL. Law 11.326, july 24 th 2006. Estabelece as diretrizes para a formulação da Política Nacional da Agricultura Familiar e Empreendimentos Familiares Rurais. Brasília, 2006.

Disponível em: < https://www.planalto.gov.br/ccivil_03/_Ato2004-

2006/2006/Lei/L11326.htm>. Acesso em: 23 nov. 2015.

BRASIL. Número de produtores orgânicos cresce 51,7\% em um ano. Brasília: Ministério da Agricultura, Pecuária e Abastecimento, 2015. Disponível em:

$<$ http://www.agricultura.gov.br/comunicacao/noticias/2015/03/numero-de-produtores-

organicos-cresce-51 porcento-em-um-ano>. Acesso em: 09 abr. 2015.

CSA BRASIL. Disponível em: < http://csabrasil.org/onde-esta-o-csa/>. Acesso em: 03 mar. 2014.

COASE, R. H. The nature of the Firm. Economica, v. 4, p. 386-405, 1937.

CUNHA, C. F. Custo de transação e mensuração nas relações contratuais entre supermercados e produtores agrícolas convencionais e orgânicos no Brasil e EUA. São Paulo: Faculdade de Economia, Administração e Contabilidade, Universidade de São Paulo. 2010.

DRd - Desenvolvimento Regional em debate (ISSNe 2237-9029) 
FELTRE, C.; PAULILLO, L. F. Contribuições para a análise de mecanismos de governança na produção rural. Agronegócio: gestão e inovação, p. 251-274, 2006.

FERREIRA, G. M. V., GONÇALVES, W. M., PEDROZO, E. A., AND TALITANE, I. C. “A Economia dos custos de transação sob uma análise crítica: perspectivas de aplicação no agronegócio" SOBER; Ribeirão Preto. 2005.

FREITAS, H.; OLIVEIRA, M.; SACCOL, A. Z.; MOSCAROLA, J. O método de pesquisa survey. Revista de Administração, v. 35, p. 105-112, 2000.

GIL, A. C. Como elaborar projetos de pesquisa. São Paulo: Atlas. 2002.

GIUCA, S. Understanding the short chain. In: GIARÈ, F.; GIUCA, S. (Eds.), Farmers and short chain: Legal profiles and sócio-economic dynamics. Italy: Istituto Nazionale di Economia Agrária, 2013.

IPD. O mercado Brasileiro de produtos orgânicos. Curitiba: Instituto de Promoção do Desenvolvimento, 2011.

KAMBARA, K. M.; SHELLEY, C. L. The California Agricultural Direct Marketing Study. Daves: U.S. Department of Agriculture and California Institute of Rural Studies, 2002.

KHERALLAH, M.; KIRSTEN, J. The New Institutional Economics: applications for agricultural policy research in developing countries. Mssd discussion paper, 2001. Washington: International Food Policy Research Institute. Disponível em: $<$ http://ageconsearch.umn.edu/bitstream/16217/1/ms010041.pdf $>$. Acesso em: 14 mar. 2015.

KNECHTEL, M.R. Metodologia da pesquisa em educação: uma abordagem teórico-prática dialogada. Curitiba: InterSaberes, 2014.

MÉNARD, C. Embedding organizational arrangements: towards a general model. Journal of Institutional Economics, v. 10, n. 4, p. 567-589, 2014.

MÉNARD, C. Organization and governance in the agrifood sector: how can we capture their variety?. Agribusiness, v. 34, p. 142-160, 2018.

NEVES, M. F. Um modelo para planejamento de canais de distribuição no setor de alimentos. São Paulo: Faculdade de Economia, Administração e Contabilidade, Universidade de São Paulo, 1997.

NORTH, D. C. Institutions. Journal of Economic Perspective, Winter, v. 5, p. 97-112, 1991.

NORTH, D. C. Institutions, institutional change and economic performance. 1990.

Cambridge: University Press. Disponível em: $<$ http://www.cambridge.org/us/academic/ subjects/politics-international-relations/political-economy/institutions-institutional-changeand-economic-performance>. Acesso em: 02 jan. 2016.

NORTH, D. C. Transaction costs, institutions, and economic performance, Discussion Paper No. 30. International Center for Economic Growth: San Francisco, 1992. 
NORTH, D. C. "Economic Performance though time". The American Economic Review, v. 84, p. 359-368, 1994.

ORGANICSNET. O mercado de orgânicos cresce o dobro no Brasil. Rio de Janeiro: Organicsnet. Disponível em: <http://www.organicsnet.com.br/2016/01/mercado-deorganicos-cresce-o-dobro-no-brasil/>. Acesso em: 30 abr. 2016.

SCHNAIDER, P. S. B.; MÉNARD, C.; SAES, M. S. M. Heterogeneity of plural forms: a revised transaction cost approach. Manage Decis. Econ., v. 39, p. 652-663, 2018.

WILLIAMSON, O. E. Transaction-Cost Economics: The Governance of Contractual Relations. Journal of Laws and Economics, v. 22, p. 233-261, 1979.

WILLIAMSON, O. E. The economic institutions of capitalism: firm, market, relational contracting. New York: The Free Press, 1985.

WILLIAMSON, O. E. Comparative economic organization: the analysis of discrete estructural anternatives, Administrative Science Quarterly, v.36, p. 269-296, 1991.

YAMAMOTO, A. Por que continuamos juntos? Reciprocidade, mudança cultural e relações de poder entre o urbano e o rural. Fortaleza: Programa de Pós-Graduação em Sociologia, Universidade Federal do Ceará, 2006.

ZYLBERSZTAJN, D. Estruturas de governança e coordenação do agribusiness: uma aplicação da nova economia das instituições. São Paulo: Faculdade de Economia, Administração e Contabilidade, Universidade de São Paulo, 1995.

ZYLBERSZTAJN, D. Papel dos Contratos na Coordenação Agro-Industrial: uma olhar além dos mercados. RER, v. 43, p. 385-420, 2005. 